\title{
INFLUENCE OF STORAGE TIME ON THE QUALITY OF BIOMASS FOR ENERGY PRODUCTION IN HUMID SUBTROPICAL REGIONS
}

\author{
Martha Andreia Brand ${ }^{1}$, Graciela Inês Bolzon de Muñiz², Waldir Ferreira Quirino ${ }^{3}$, José Otávio Brito ${ }^{4}$
}

(received: February 12, 2009; accepted: July 29, 2010)

\begin{abstract}
This work aims to determine an optimal storage time of forest biomass for use in energy production, through analysis of variations in physical and chemical properties of with bark timber over the storage period. The study was conducted in the municipality of Lages, SC, over a span of 18 months. The experiment used with bark logs of Pinus taeda and Eucalyptus dunnii, with varying diameters, and slabs of Pinus spp., stored in piles. The material was sampled freshly harvested (control), after two, after four and after six months of storage. Four lots were used, harvested and stored at the spring, summer, autumn and winter seasons. Properties being assessed included moisture content (wet basis), gross calorific value, net calorific value and ash content. Results demonstrated that storage time influenced moisture content and net calorific value, yet it had no influence on gross calorific value and ash content. Optimal storage time ranged from two to four months, depending on the species, form of biomass and storage season. The best behavior regarding quality after storage was from Pinus slabs, followed by Eucalyptus logs and Pinus logs, the latter showing the worst behavior.
\end{abstract}

Key words: Energy properties, Pinus taeda, Eucalyptus dunnii, storage time of forest biomass.

\section{INFLUÊNCIA DO TEMPO DE ESTOCAGEM NA QUALIDADE DA BIOMASSA PARA ENERGIA EM REGIÕES SUBTROPICAIS ÚMIDAS}

\begin{abstract}
RESUMO: Objetivou-se, neste trabalho, determinar o tempo ideal de estocagem da biomassa florestal, para uso na geração de energia, através da análise da variação das propriedades físicas e químicas da madeira com casca, durante o período de armazenamento. $O$ estudo foi realizado no Município de Lages, SC, durante 18 meses. No experimento foram utilizadas toras com casca de Pinus taeda e Eucalyptus dunnii, de diâmetros variados, e costaneiras de Pinus spp., estocadas em pilhas. O material para análise foi coletado no estado recém colhido (testemunha), com dois, quatro e seis meses de estocagem. Foram utilizados quatro lotes, colhidos e estocados nas épocas de primavera, verão, outono e inverno. As propriedades avaliadas foram: teor de umidade na base úmida, poder calorífico superior e líquido e teor de cinzas. Com os resultados demonstrou-se que o tempo de estocagem teve influência sobre o teor de umidade e poder calorífico líquido, mas não sobre o poder calorífico superior e teor de cinzas. O tempo ideal de estocagem variou entre dois a quatro meses, dependendo da espécie e forma da biomassa é época do ano em que foi realizada a estocagem. O material de melhor qualidade após estocagem foi a costaneira de Pinus, seguida das toras de Eucalyptus. O pior comportamento foi das toras de Pinus.
\end{abstract}

Palavras-chave: Propriedades energéticas, Pinus taeda, Eucalyptus dunnii, tempo de estocagem de biomassa florestal.

\section{INTRODUCTION}

Treatment of biomass has been increasingly discussed and evaluated as a mechanism for improving the properties of biomass intended for energy production. Treatment comprises several stages, and one of them is storage, possibly involving a few days or weeks, or extending over months or even years in countries with severe, long winters. Treatment procedures may be performed at the source or at the end use location and involve several operating methods (pile storage, large wood pieces or wood chips, indoors or outdoors etc).

The length of time biomass should remain in storage is a critical factor to be considered (GARSTANG et al., 2002; JIRJIS, 1995; 2005; NURMI, 1990; 1995; THÖRNQVIST, 1984; 1985; 1986), since storage influences not only changes in physical and chemical properties of biomass but also operating costs to be met by the biomass

\footnotetext{
${ }^{1}$ Forest Engineer, Professor Dr. in Forest Engineering - Departamento do Engenharia Florestal - Universidade do Estado de Santa Catarina - Luiz de Camões, 2090, Bairro Conta Dinheiro - 88520-000 - Lages, SC - a2mab@cav.udesc.br

${ }^{2}$ Forest Engineer, Professor Dr. in Forest Engineering - Departamento de Engenharia e Tecnologia Florestal - Universidade Federal do Paraná - Av. Prof. Lothário Meissner, 900, Jardim Botânico - 80210-170 - Curitiba, PR - gbmunize@ufpr.br

${ }^{3}$ Forest Engineer, Dr. in Wood Sciences - IBAMA - SCEN, Trecho 2, Ed. Sede - Cx. P. 09566 - 70818-900 - Brasília, DF waldir.quirino@ibama.gov.br

${ }^{4}$ Forest Engineer, Professor Dr. in Soils and Plant Nutrition - Universidade Federal de São Paulo - Escola Superior de Agricultura Luiz de Queiroz - Av. Pádua Dias, 11 - Cx. P. 09 - 13418-900 - Piracicaba, SP - jotbrito@esalq.usp.br
} 
power plant. It has direct implications on raw material immobilization and space used in conducting the activity.

Properties most affected by storage include moisture content, basic density, chemical composition, calorific value and ash content, all of which may serve as quality parameters to determine whether the biomass should be discarded or used for energy production.

As regards moisture content, Thörnqvist (1984, 1985) observed while studying wood chips and other large forest residue that drying is more effective over the first two to four months of storage. If storage time is extended, however, the moisture content in the piles rises, possibly reaching the same level as found initially after six to nine months. This is due to the breakdown of the lignincellulose structure and resulting moisture increase (THÖRNQVIST 1984). On the topic of biomass storage time, Nurmi (1995) argues that, even with drying occurring in the summer, moisture is nonetheless reabsorbed if storage is extended over autumn or winter months.

Moisture content directly affects calorific value, mass loss and fungal growth in biomass during storage. Net calorific value and mass loss, in turn, directly affect the energy content of the fuel (THÖRNQVIST 1984).

As for gross calorific value, Jirjis (2005), Nurmi (1990, 1995) and Thörnqvist $(1984,1985,1986)$ agree that this property remains relatively stable over the initial months of biomass storage (up to four months), whether chipped or logged, then rises between 14 and 18 months, decreasing afterward. The only authors observing significant variations in the calorific value of biomass over time were Garstang et al. (2002). These authors ascribed variations to changes in the chemical composition of extracellular components (extractives) right from initial stages of storage, affecting biodegradation processes and even forming compounds with higher energy potential in some cases.

Net calorific value is a critical element when the topic is storage time, with moisture content, widely variable during storage, exerting great influence on this property of biomass. Nurmi (1995) observed significant gains in net calorific value of forest biomass if stored up to 18 months. Periods beyond that no longer contribute positively to energy gains due to chemical changes occurring in the biomass.

Where long storage periods are involved, wood decomposition leads to changes in proportions of cellulose and lignin. If the lignin content increases, which is likely to occur due to brown rot fungus, then gross calorific value also increases (GARSTANG et al. 2002, JIRJIS 1995, SJÖSTRÖM 1993, THÖRNQVIST 1986). With the decomposition of organic materials, an increasing percentage of inorganic material (ashes) will follow (THÖRNQVIST 1982, as cited by THÖRNQVIST 1985).

Garstang et al. (2002) observed drastic shifts in the ash content of biomass throughout storage, probably due to sampling being performed at random. Jirjis (2005), on the other hand, found no significant variations in ash contents of forest biomass throughout storage, while Thörnqvist (1986) observed a slight increase over a ninemonth storage period.

From what has been said, storage time should be sufficient to reduce the moisture content in biomass and yet prevent energy losses due to loss of dry mass, from decay or handling, that way increasing energy gains and helping keep costs down for this operation. Storage may be influenced by several factors, including site, season, type and composition of biomass, and desired grading of properties for energy production.

This work aims to determine an optimal storage time of forest biomass, in the form of logs and slabs, through analysis of variations in the physical and chemical properties of the biomass, for use in energy production in cogeneration systems.

\section{MATERIAL AND METHODS}

The study was conducted in Lages, a town in Santa Catarina, between October 2003 and February 2005. Lages lies at latitude $27^{\circ} 30^{\prime}$ south and longitude $50^{\circ}$ west, at an altitude of 800 to $900 \mathrm{~m}$. According to Köppen classification, the local climate is $\mathrm{Cfb}$ type, characterized by mild summers and no water deficit (LEITE et al. 1973). Meteorological data for the study period are provided in Table 1 .

The experiment used with bark logs of Pinus taeda and Eucalyptus dunnii about $2.4 \mathrm{~m}$ in length, with varying diameters", and slabs ${ }^{* *}$ of Pinus taeda about $2 \mathrm{~m}$ in length, with or without bark. Each material was stored separately in piles ( $6 \mathrm{~m}$ in length $\times 2.5 \mathrm{~m}$ in width $\times 2.5 \mathrm{~m}$ in height). Four lots were analyzed of each material, in storage for six months, with samples being collected soon after harvest, after two, four and six months, and with storage occurring at different times of the year (Table 2).

\footnotetext{
*Log diameters ranged from $8 \mathrm{~cm}$ to 30 plus $\mathrm{cm}$, since the relevant material consisted of timber intended for energy production (thin $\log s$ ) and discarded $\log$ s from industrial processes (thick $\log s$ ), noting that this variable was not controlled in this study.

${ }^{* *}$ Slab is a half-moon shaped wood piece obtained from squaring logs into cants by using primary breakdown saws.
} 
Table 1 - Climate conditions in Lages - SC (October 2003 to February 2005) ${ }^{* * *}$.

Tabela 1 - Condições climáticas de Lages - SC (outubro de 2003 a fevereiro de 2005)***.

\begin{tabular}{|c|c|c|c|c|c|c|c|c|c|c|c|c|c|c|c|c|c|}
\hline \multirow{3}{*}{ Data } & \multicolumn{17}{|c|}{ Year } \\
\hline & \multicolumn{6}{|c|}{2003} & \multicolumn{5}{|c|}{2004} & \multicolumn{6}{|c|}{2005} \\
\hline & Oct & Nov & Dec & Jan & Feb & Mar & Apr & May & Jun & Jul & Aug & Sep & Oct & Nov & Dec & Jan & Feb \\
\hline Precipitation (mm) & 119 & 94 & 225 & 81 & 114 & 144 & 82 & 103 & 28 & 233 & 52 & 278 & 162 & 104 & 136 & 147 & 47 \\
\hline Temperature $\left({ }^{\circ} \mathrm{C}\right)$ & 18 & 19 & 20 & 21 & 21 & 20 & 19 & 13 & 13 & 12 & 14 & 17 & 17 & 19 & 20 & 22 & 22 \\
\hline Relative humidity (\%) & 76 & 72 & 79 & 78 & 76 & 77 & 83 & 85 & 82 & 84 & 77 & 82 & 75 & 76 & 76 & 76 & 75 \\
\hline
\end{tabular}

Source: EPAGRI (2006)

Table 2 - Experimental design used in the biomass storage study.

Tabela 2 - Delineamento experimental utilizado no estudo de estocagem de biomassa.

\begin{tabular}{|c|c|c|c|c|c|c|c|c|c|c|c|c|c|c|c|c|c|}
\hline \multirow{2}{*}{$\begin{array}{l}\text { Year } \\
\text { Month }\end{array}$} & \multicolumn{6}{|c|}{2003} & \multicolumn{5}{|c|}{2004} & \multicolumn{6}{|c|}{2005} \\
\hline & 10 & 11 & 12 & 01 & 02 & 03 & 04 & 05 & 06 & 07 & 08 & 09 & 10 & 11 & 12 & 01 & 02 \\
\hline Lot 1 & $X$ & $X$ & & & & $X$ & & $X$ & & & & & & & & & \\
\hline Lot 2 & & & & $X$ & & & $X$ & & $X$ & & $X$ & & & & & & \\
\hline Lot 3 & & & & & & & & $X$ & $X$ & & & $X$ & & $X$ & & & \\
\hline Lot 4 & & & & & & & & & & & $X$ & & $X$ & $\mathrm{X}$ & & & $X$ \\
\hline
\end{tabular}

Shaded boxes indicate the period of lot assessment and boxes marked with an $\mathrm{X}$ indicate sampling moments.

Samples were collected from the base, middle and top of piles. With the bark left on, logs and slabs were turned into chips for determination of physical and chemical properties. Moisture content (wet basis), gross calorific value, net calorific value and ash content were analyzed according to standards NBR 14929, DIN 51900, and TAPPI 211 respectively (ASSOCIAÇÃO BRASILEIRA DE NORMAS TÉCNICAS-ABNT 2003, DEUTSCHES INSTITUT FÜR NORMUNG-DIN 2000, STANDARD TEST METHODS-TAPPI 1994).

The statistical treatment used the F-test and the Tukey test $(\mathrm{P}>0.05)$. A trend chart was created and a model was fitted, using regression analysis, for moisture content and net calorific value properties, relating these properties to storage time.

\section{RESULTS AND DISCUSSION}

Results of physical and chemical properties over the six-month storage period are provided in Table 3.

\footnotetext{
${ }^{* * *}$ In 2004 , total annual precipitation was $1,517 \mathrm{~mm}$, average temperature was $17^{\circ} \mathrm{C}$ and relative humidity was $79 \%$. Data depict local climate conditions in typical years.
}

Biomass properties influenced by storage time are moisture content and net calorific value, the former decreasing and the latter increasing throughout. An analysis is provided below of each of these propertiesmoisture content and net calorific value only-, with trend charts and model fitting relative to storage time.

As regards gross calorific value, even though Pinus slabs showed a significant variation over the storage period, in practical terms it is unimportant since for purposes of energy production only differences above $300 \mathrm{Kcal}$ are considered.

Ash content remained unaltered as a function of storage time (Table 3), agreeing with results found by Jirjis (2005). This is due to there being no changes in the composition of wood cell structure, as was observed by Brand (2007) while studying the same material as in this paper. Eucalyptus logs showed a significant variation over the storage period. This observed behavior, however, was influenced by natural variations within the species and by the sampling process, rather than by storage time, as observed by Garstang et al. (2002) and Jirjis (2005).

Differences between species and the form in which materials are stored also influence biomass behavior throughout the storage period (BRAND 2007).

Cerne, Lavras, v. 16, n. 4, p. 531-537, out./dez. 2010 
Table 3 - Variation in physical and chemical properties of forest biomass as a function of storage time.

Tabela 3 - Variação das propriedades físicas e químicas da biomassa florestal em função do tempo de estocagem.

\begin{tabular}{|c|c|c|c|c|c|c|c|c|c|c|c|}
\hline \multirow{2}{*}{ Variable } & \multicolumn{11}{|c|}{ Biomass type } \\
\hline & \multicolumn{3}{|c|}{ Pinus logs } & \multicolumn{3}{|c|}{ Eucalyptus $\operatorname{logs}$} & \multicolumn{3}{|c|}{ Pinus slabs } & \multicolumn{2}{|c|}{ Mean values } \\
\hline \multicolumn{12}{|c|}{ Moisture content, wet basis (\%) } \\
\hline Newly harvested & 59 & $\mathrm{a}$ & (a) & 54 & $\mathrm{a}$ & (a) & 54 & a & (a) & 56 & $\mathrm{a}$ \\
\hline Two months & 58 & a & (a) & 43 & $\mathrm{~b}$ & (b) & 28 & $\mathrm{~b}$ & (c) & 44 & $\mathrm{~b}$ \\
\hline Four months & 46 & $\mathrm{~b}$ & (a) & 34 & $\mathrm{bc}$ & (b) & 14 & $\mathrm{c}$ & (c) & 33 & $\mathrm{c}$ \\
\hline Six months & 51 & $\mathrm{ab}$ & (a) & 32 & $\mathrm{c}$ & (b) & 28 & $\mathrm{~b}$ & (b) & 38 & $\mathrm{bc}$ \\
\hline \multicolumn{12}{|c|}{ Gross calorific value ( $\mathrm{kcal} / \mathrm{kg}$ ) } \\
\hline Newly harvested & 4788 & a & (a) & 4542 & a & (b) & 4743 & $\mathrm{~b}$ & (a) & 4686 & $\mathrm{a}$ \\
\hline Two months & 4806 & a & (a) & 4615 & a & (b) & 4779 & $\mathrm{ab}$ & (a) & 4729 & $\mathrm{a}$ \\
\hline Four months & 4839 & a & (a) & 4617 & a & (b) & 4715 & $\mathrm{~b}$ & (b) & 4724 & $\mathrm{a}$ \\
\hline Six months & 4792 & $\mathrm{a}$ & (a) & 4606 & $\mathrm{a}$ & (c) & 4845 & $\mathrm{a}$ & (a) & 4739 & $\mathrm{a}$ \\
\hline \multicolumn{12}{|c|}{ Net calorific value (kcal/kg) } \\
\hline Newly harvested & 1479 & $\mathrm{~b}$ & (a) & 1646 & $\mathrm{c}$ & (a) & 1741 & $\mathrm{c}$ & (a) & 1611 & $\mathrm{c}$ \\
\hline Two months & 1545 & $\mathrm{~b}$ & (c) & 2204 & $\mathrm{~b}$ & (b) & 3056 & $\mathrm{~b}$ & (a) & 2197 & $\mathrm{~b}$ \\
\hline Four months & 2198 & a & (b) & 2624 & $a b$ & (b) & 3674 & a & (a) & 2756 & $\mathrm{a}$ \\
\hline Six months & 1875 & $\mathrm{ab}$ & (b) & 2746 & $\mathrm{a}$ & (a) & 3093 & $\mathrm{~b}$ & (a) & 2524 & $a b$ \\
\hline \multicolumn{12}{|l|}{ Ash content $(\%)$} \\
\hline Newly harvested & 0.45 & $\mathrm{a}$ & (a) & 0.78 & $\mathrm{ab}$ & (a) & 0.33 & $\mathrm{a}$ & (a) & 0.54 & $\mathrm{a}$ \\
\hline Two months & 0.41 & $\mathrm{a}$ & (b) & 1.02 & a & (a) & 0.30 & $\mathrm{a}$ & (b) & 0.60 & $\mathrm{a}$ \\
\hline Four months & 0.39 & $\mathrm{a}$ & (a) & 0.61 & $\mathrm{~b}$ & (a) & 0.31 & $\mathrm{a}$ & (a) & 0.45 & $\mathrm{a}$ \\
\hline Six months & 0.43 & $\mathrm{a}$ & (b) & 0.97 & $\mathrm{a}$ & (a) & 0.35 & $\mathrm{a}$ & (b) & 0.60 & $\mathrm{a}$ \\
\hline
\end{tabular}

Please note: means followed by the same letter do not significantly differ (Tukey P> 0.05). Letters outside parentheses - a, b, $c$ designate variation in the property over the storage period (newly harvested, 2, 4 and 6 months of storage). COLUMN analysis. Letters inside parentheses - (a), (b)... - designate variation in material over the same storage period. ROW Analysis.

\subsection{Moisture content}

Storage time had an influence on the moisture content, a significant variation being observed in this property throughout the storage period (Table 3 ).

Moisture content was found to be high in newly harvested material, for all three biomass types, decreasing more intensely over the first four months in Pinus slabs, followed by Eucalyptus dunnii logs and less intensely by Pinus logs. While Eucalyptus logs continually lost moisture up until six months of storage, Pinus logs and Pinus slabs started to reabsorb moisture after four months of storage (Figure 1 (a)). This tendency was similar to that found by Thörnqvist (1984, 1985). However, at the end of the sixmonth period, moisture content values did not equalize initial values, as observed by the author.

Cerne, Lavras, v. 16, n. 4, p. 531-537, out./dez. 2010
Each biomass type showed a distinct behavior, indicating that the form in which biomass is stored (logs or slabs) exerted greater influence on the rate of moisture loss than the species itself. Slabs lost more moisture, followed by Eucalyptus logs and then Pinus logs.

Even considering the differences inherent in species and form of biomass, there is nonetheless a decreasing tendency in moisture content throughout storage, more pronounced in the first four months, and a reduction in the rate of moisture loss for Eucalyptus, while for Pinus, regardless of the biomass form, there was absorption of moisture from four to six months of storage (Figure 1 (b)).

Brand (2007) argued that, other than storage time and biomass form, the storage season also influences moisture loss, with spring and summer being more favorable 

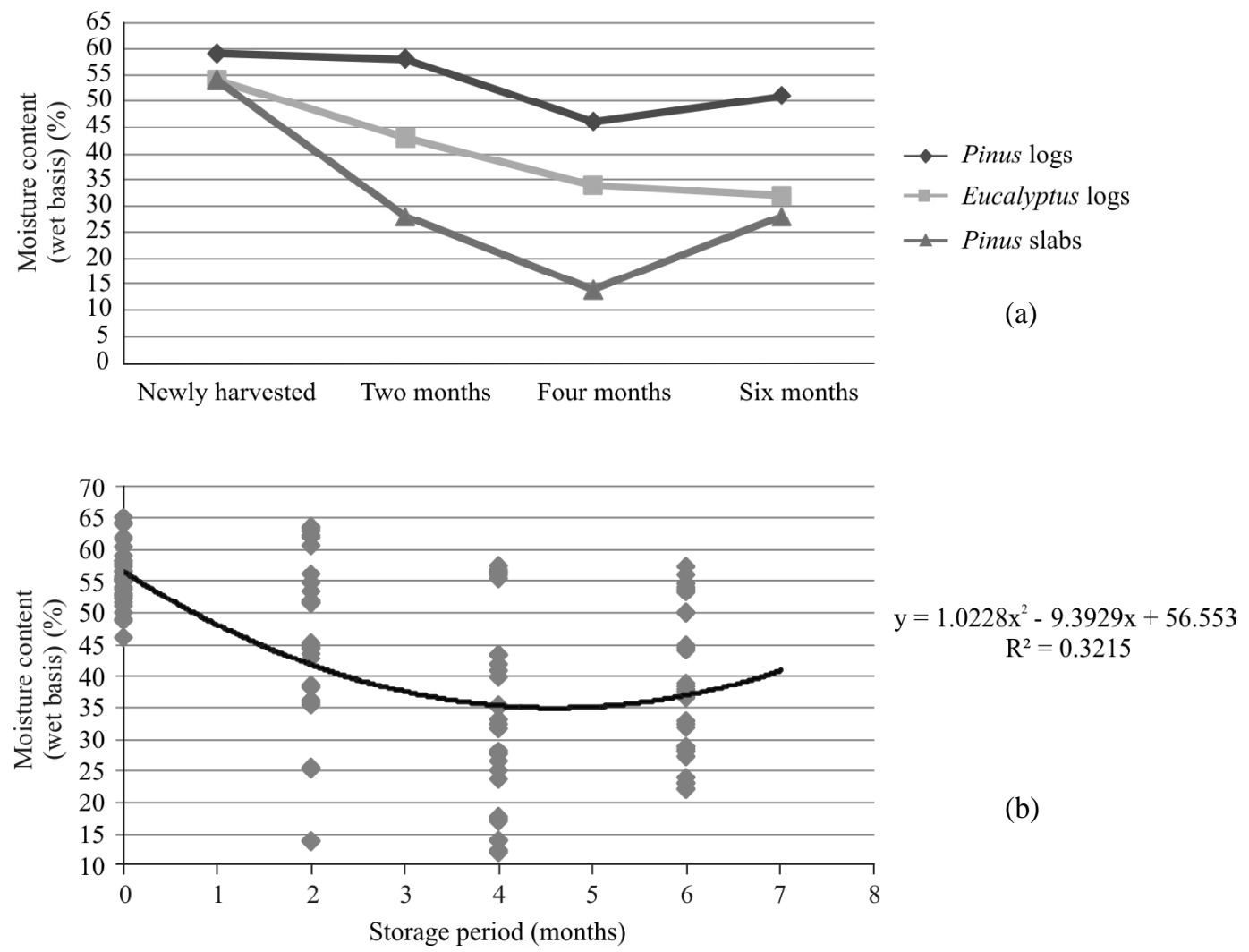

Figure 1 - Variation in moisture content (wet basis) of forest biomass as a function of storage time.

Figura 1 - Variação do teor de umidade na base úmida da biomassa florestal, em função do tempo de estocagem.

than autumn or winter. This behavior is related to climate conditions, which differ from summer to winter in the relevant study site. Relative humidity is higher and temperatures are lower in the winter, delaying water evaporation from the biomass. Also, the amount of water present in newly harvested biomass influences the rate of moisture loss.

Moisture content required to ensure good biomass performance in power generation systems being $30 \%$ or less (BRITO \& BARRICHELLO 1982, GARSTANG et al. 2002), Pinus logs failed to meet this requirement, not even with six months of storage. Pinus slabs reached the required average moisture content with two months, while Eucalyptus logs reached it with four months. Therefore, the optimal storage time for with bark Eucalyptus logs and Pinus slabs was two to four months, with Pinus logs not being recommended for storage.

\subsection{Calorific value}

Storage time demonstrated not to influence the gross calorific value of forest biomass (Table 3), agreeing with results found by Jirjis (2005), Nurmi (1990, 1995) and Thörnqvist (1985, 1986).

Over a six-month span, however, a slight increasing tendency was observed in gross calorific value relative to storage. Thus, gross calorific value can be expected to increase up to a certain limit, prior to the degradation of cell wall components, particularly lignin, and then decrease.

Still on net calorific value, a significant difference was observed for this variable as a function of storage time (Table 3). The behavior of this property was inversely proportional to the moisture content, increasing continually until the end of the storage period for Eucalyptus, and until four months of storage for Pinus, then decreasing afterward (Figure 2).

The mean net calorific value of newly harvested material was lower and statistically similar between species, and different between two, four and six months of storage for Pinus slabs and Eucalyptus logs. For Pinus logs, newly harvested material was different only for four months of

Cerne, Lavras, v. 16, n. 4, p. 531-537, out./dez. 2010 

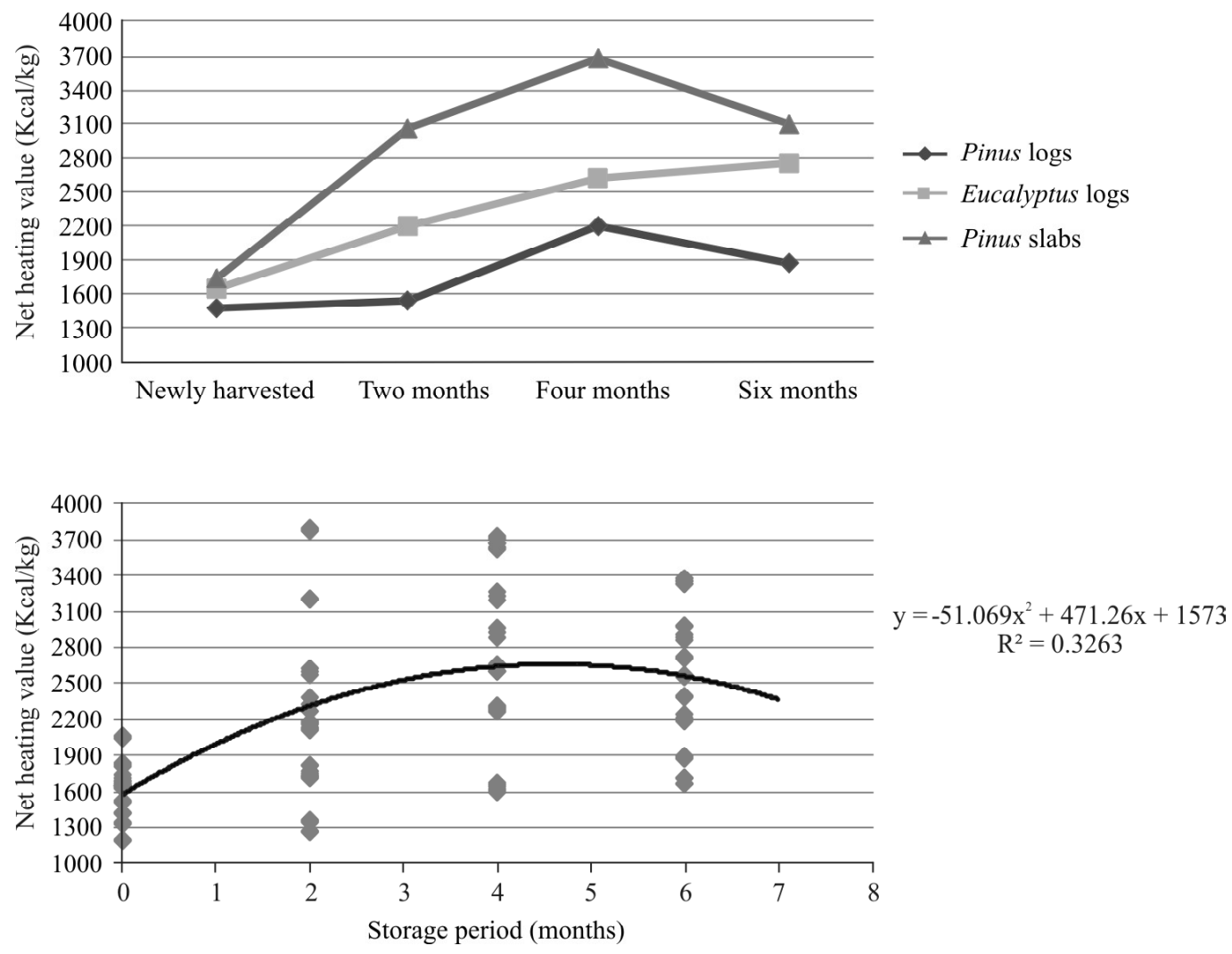

Figure 2 - Variation in net calorific value of forest biomass as a function of storage time.

Figura 2 - Variação do poder calorífico líquido da biomassa florestal, em função do tempo de estocagem.

storage. The highest values for Pinus were recorded at four months, while the highest value for Eucalyptus was recorded at six months, similar to that at four months.

Gains in net calorific value throughout the storage period for Pinus logs, Eucalyptus logs and Pinus slabs were $49 \%, 59 \%$ and $111 \%$ respectively, relative to initial values, after four months of storage, yet with Eucalyptus the calorific value continued to increase until six months of storage, amounting to $67 \%$ gains in relation to initial values.

In terms of net calorific value, the optimal storage time was four months, considering collectively moisture loss and gains in net calorific value.

\section{CONCLUSIONS}

Storage time, from zero to six months, influenced the quality of forest biomass for energy production, improving biomass quality up until four months in the case of Pinus, and up until six months in the case of Eucalyptus.
Storage time significantly influenced moisture content and net calorific value, lowering the moisture content and increasing the net calorific value throughout, yet it did not significantly influence the gross calorific value or ash content, both properties remaining stable throughout.

Storage time is influenced by biomass species, biomass form, and storage season.

The optimal storage time ranged from two to four months, depending on the species and form of biomass.

Pinus slabs showed the best behavior in storage, followed by Eucalyptus logs.

Other than biomass quality, other factors determining storage time will be costs of raw material immobilization, space availability and demand for energy.

\section{BIBLIOGRAPHICAL REFERENCES}

ASSOCIAÇÃO BRASILEIRA DE NORMAS TÉCNICAS. NBR 14929: Madeira: determinação do teor de umidade de cavacos: método por secagem em estufa. Rio de Janeiro, 2003.

Cerne, Lavras, v. 16, n. 4, p. 531-537, out./dez. 2010 
BRAND, M. A. Qualidade da biomassa florestal para o uso na geração de energia em função da estocagem. 2007. 165 p. Monografia (Pós-graduação em Ciências Florestais) Universidade Federal do Paraná, Curitiba, 2007.

BRITO, J. O.; BARRICHELO, L. E. G. Aspectos técnicos da utilização da madeira e carvão vegetal como combustíveis. In: SEMINÁRIO DE ABASTECIMENTO ENERGÉTICO INDUSTRIAL COM RECURSOS FLORESTAIS, 2., 1982, São Paulo. Anais... São Paulo: Governo do Estado de São Paulo, 1982. p. 101-137.

DEUTSCHES INSTITUT FÜR NORMUNG. DIN 51900: determining the gross calorific value of solid and liquid fuels using the bomb calorimeter, and calculation of net calorific value. Berlin, 2000.

EPAGRI. Estação meteorológica. Lages, 2006.

GARSTANG, J.; WEEKES, A.; POULTER, R.; BARTLETT, $D$. Identification and characterisation of factors affecting losses in the large-scale, non-ventilated bulkstorage of wood chips and development of best storage practices. [S.1.]: FES, 2002. 116 p. Relatório técnico.

JIRJIS, R. Effects of particle size and pile height on storage and fuel quality of comminuted Salix viminalis. Biomass and Bioenergy, v. 28, p. 193-201, 2005.

JIRJIS, R. Storage and drying of wood fuel. Biomass and Bioenergy. v. 9, n. 1/5, p. 181-190, 1995.

LEITE, N. B.; FERREIRA, M.; RAMOS, P. G.; GUTIERREZ NETO, F. Efeito de geadas sobre diversas espécies/procedências de Eucalyptus spp introduzidas na região de Lages, Santa Catarina. IPEF, Piracicaba, n. 7, p. 101-114, 1973.

NURMI, J. The effect of whole-tree storage on the fuelwood properties of short-rotation Salix crops. Biomass and Bioenergy, v. 8, n. 4, p. 245-249, 1995.

NURMI, J. Longterm storage of fuel chips in large piles. Folia Forestalis, n. 767, p. 1-18, Aug. 1990.

SJÖSTRÖM, E. Wood chemistry: fundamentals and applications. 2. ed. Davis: Academic, 1993. 293 p.

STANDARD TEST METHODS. Technical association for the woldwide pulp, paper and converting industry: TAPPI 211: ash in wood, pulp, paper and paperboard: combustion at $525^{\circ} \mathrm{C}$. Atlanta, 1994.

THÖRNQVIST, T. Drying and storage of forest residues for energy production. Biomass, London, v. 7, p. 125-134, 1985.

THÖRNQVIST, T. Projekt storskalig säsongslagring av trädbraänsle: en sammanfattning av etapp 1, large-scale seasonal storage of tree fuel project: summary of phase 1. Sweden: The Swedish University of Agricultural Sciences, 1986. 50 p. (Report, 188).

THÖRNQVIST, T. Storing of forest residues and comminuted fuels from forest residues. In: CONFERENCE HELD BY THE INTERNATIONAL ENERGY AGENCY, 1984, Denmark. Proceedings... Denmark: Danish Institute of Forest Technology, 1984. p. 16-18. 
